\section{1. 分子ロボティクスとは}

デバイス群がシステム化されると，ロボットにな る、著者らの取り組む学問分野である分子ロボティク スでは，さまざまな分子デバイスを設計しシステム化 することによって，動作をプログラムできるような分 子複合構造「分子ロボット」の構築 ${ }^{1)}$ を目指している. それを通じて，自然界では使われていない生体分子シ ステムの潜在能力を発見し，利用することが目的であ る. 本学会年会でも幾度かシンポジウムが開催されて おり，生物物理学をはじめ化学，工学など分野を横断 して活発な研究が行われている. 生物物理学は基礎と 応用の両面を持っている2) と言われるが，分子ロボ ティクスはまさにその好例である。

分子ロボティクスの重要なキーワードの一つに分子 デザインがある，その対象は分子構造，刺激に対する 分子の応答や分子反応のネットワークなどさまざまで ある．分子ロボットをデザインする上で有用な技術の 一つが「DNAナノテクノロジー」である。これは, DNA 分子の 4 種の塩基（A, T, G, C）の配列を任意の 二重らせんが形成されるようにデザィンすることで構 造や反応経路などを作製するものである. 数千におよ ぶ塩基配列を，こんがらからないよらにすべて人の手 で設計することは極めて困難であるが，近年では DNA 構造設計支援のための Web ツール (caDNAno) などが公開されている。そして，合成 DNAのコスト も 1 塩基あたり数十円と下落したことから, DNA 分 子デザインを始めるにあたっての障壁は劇的に下がっ てきている．また，DNAを用いて分子反応のネット ワークをデザィンすることで，分子デバイスとその制
御用計算回路をまとめて一種類の分子で配線（Wiring）できることも大きな利点である。こうした背景 のもと，米国の Shawn Douglas 博士らの発案によって 2011 年から米 Harvard 大 Wyss 研究所主催によって開 催されているのが国際学生生体分子デザィンコンペ ティション, BIOMODである[Biomod.net].

\section{BIOMOD とは}

BIOMOD は，生体分子（核酸，タンパク質，脂質 など）を材料とする人工分子のデザイン大会である. 学部学生がチームを組み，テーマを決めて約半年の活 動を行ら。実験の大部分は夏休みを利用して行われ, プロジェクトの紹介Web ページと動画を作成し，11月 に米国での本大会（Jamboree と呼ばれる）でプレゼン テーションを行ってその出来映えを競う。教員や先輩 学生はアドバイザ・メンターとして参加する．毎年世 界中からチームが参加して和り，昨年は12の国と地 域から 30 チームが Jamboree 会場のボストンに集まっ た。今年の舞台は西海岸 UCSFである。

日本からも2011 年の初年度より毎年複数のチーム が参戦して扣り，独自に国内中間大会（本大会と同様 の採点方式）を開催するなど大いに盛り上がっている. 同様の大会としては，先輩筋にあたる合成生物学の学 生コンペティションiGEMが有名である [igem.org]. 生 物改造選手権の iGEM, 分子工作選手権の BIOMOD, といった棲み分けであろらか. BIOMODでは，設定す るテーマは「分子をデザイン」していれば何でも OK である，ちなみに，2015 年大会の総合優勝は，単独種 の分子によって直線状の重合数=長さが制御できる, といらプロジェクトだった．分子はDNAオリガミで

\title{
BIOMOD: Road to Molecular Robotics
}

Yusuke SATO ${ }^{1,2}$, Masahiro TAKINOUE ${ }^{3}$ and Shin-ichiro M. NOMURA ${ }^{1}$

${ }^{1}$ Department of Robotics, Graduate School of Engineering, Tohoku University

${ }_{2}^{2}$ JSPS research fellow (DC2)

${ }^{3}$ Department of Computational Intelligence and Systems Science, Interdisciplinary Graduate School of Science and Engineering, Tokyo Institute of Technology 
デザインされ，筒と，その内部に回転できる「ねじれ た」シャフトがある，この筒が直線状に連結するごと に内部のシャフトのねじれ角が蓄積して, 重合数が決 定される，といらものであった ${ }^{3)}$.

チームプロジェクトの評価には明確な基準があり, オリジナリティと達成度, 説明の明瞭さが重視されて いる。そして，プロジェクトを紹介するための Web ページと３分の動画，Jamboree（本大会）での成果発 表の合計得点で賞が決まる，各国のチームがしのぎを 削る中で, プロの研究者に匹敵する取り組みや成果を 見せるチームもある，たとえば，2013 年大会で総合 優勝した独 LMUチームのプロジェクトは, 2015 年に 学術論文として報告されている ${ }^{4)}$.

このイベントを教育的な側面から見てみよう。学部 生にとって，いきなりプロジェクトの立案から実験・ まとめ・プレゼンテーションまでのすべてを行い，外 部審査員に評価され順位づけられるといら経験は相当 にタフなものである。したがって，学生は控えめに 言って飛躍的に成長する，言語はもちろんすべて英語 であり（この点は多くの日本人学生にとって最大の困 難とも言える), 留学生と仲良くなったり, 大会後に 留学したりと，急速に英語力を伸ばすきっかけでもあ る.メンターとして学部生を指導する先輩学生, 院生 らにとっても実験結果の解釈や文章の添削を通じて学 ぶ機会が多い，一方で，科学的に足りない部分や説明 不足を見抜き，チームを磨くアドバイザの役割もまた 大きい.

\section{3. 経験談話室}

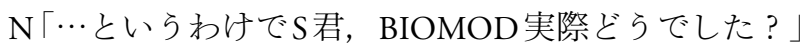
$S 「 の め り$ 込みましたね。頭の中で想像した分子の様 子が，たとえばDNAオリガミは透明な液体でもちろ ん見えないけれど，混ぜて温めて冷やして（AFMで） 吒いて観ると確かに設計通りの構造がある。初めて見 たときは感動しました，設計通りにできた面白さ，そ してできない時の謎解き大会. ぼくらが出場した第 1 回大会では絶対に自分たちが 1 位だと思いました。結 構頑張った‥でも勝てなかった．テーマの明快さ，伝 えることの重要性に気づかされました.」

$\mathrm{N} 「$ 君ら悔しがってリベンジを直訴にきたもんなあ, 夜中に。. ‥⿱一尢 初年度いきなり世界 2 位のアドバイザ T氏じゃないですか. いかがでした？」

$\mathrm{T} 「$ 「や，あれ正直大変ですよ，場所提供したり助言 したりの他, 学部学生を海外に連れて行けるよらなグ ラントを探して申請したり。でも学生が䪹張ってる と，できることはしてあげたくなる（笑）」
N「アイディア持ち込んでくる学生を片っ端から迎撃 する “醍醐味”も，ですね．大会後のくらしはどう？」 S「BIOMOD は自由な発想で自由にプロジェクトを進 められる大会なので，そこに参加した自分たちだから こそ生み出せる価值観がある，といら思いで過ごして います。夢中で研究できる現役 BIOMODer が正直羡 ましいですね（笑），先輩としても彼らから質問され て答えられないのは嫌なので，つい先回りして調べ物 をしてしまう。彼らの文章を添削すると自分が書くと きの参考になることが多いです.」

$\mathrm{N}$ 「教員も教員で，つい口を出したくなる，と」 T「でその口出しをまとめると妙にアッい教科書 ${ }^{5)}$ できて，無料配布される，と」

$S 「$ 旧世代からのご支援ありがとらございます！」 $\mathrm{N} \& \mathrm{~T}\lceil\cdots$ 旧！」

\section{4. 次世代の研究者による分子ロボティクス}

BIOMOD 大会から次世代の研究者が続々と育つ か？と問われたならば，甲子園球児とプロ野球選手の 関係に近いと答えるのが当たらずといえども遠から ず，だろらか. BIOMODを絶好のトレーニングの機 会として，その経験をもとに分子ロボティクスに挑戦 し続ける若手が確実に残っており，BIOMODメン タ一たちの立ち上げた「分子ロボティクス若手の会」 が年 2 回開催と八イペースな活動を続けている ${ }^{6}$.

さて，人工の分子デバイス群をシステム化するとい ら分子ロボットのデザインの一つに, 脂質膜小胞（リ ポソーム）をシャシーとして分子デバイス群，分子機 械たちをインストールするボトムアップ様式の「人工 細胞タイプ」があり，BIOMOD でもしばしば提案さ れている，ただ袋に全溶液を混ぜるだけでなく，分子 のふるまいをいかにプログラムするか, つまり人の意 思を分子の現場にどのように伝えるか，といら部分が 今後の研究の焦点になる. 人工 DNA 回路による配線 はその一例であり，遺伝子発現系やエネルギー変換系 など，生物から抽出・精製・改変された組久込久可能 な制御用分子回路が次々実装され，制御方法が編み出 されてゆくだろら。今はまだ簡単な運動の ON/OFF スイッチしかできない分子ロボットであるが，今後の 複雑化・精緻化によって既存の生命システムを超える 分子システムを人間が作れるよらになった時，生体分 子システムについて本当に分かったと言え，その先に 天然と人工の壁を越えた人間の活動を拡大できるよう な本当の分子工学が誕生するのではないだろらか，そ れを実現するきっかけが学生の力であったなら，相当 に痛快であろら。学生大会が分子レベルからのデザイ 


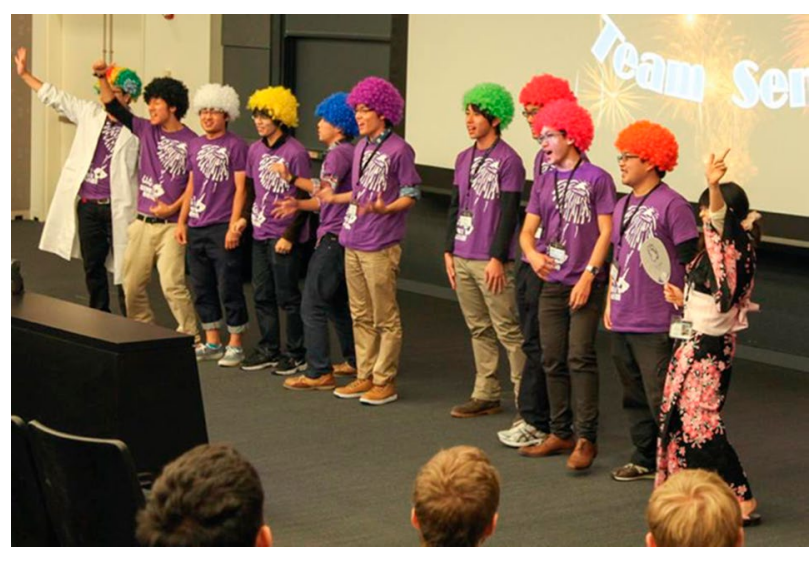

図 1

BIOMOD 本大会発表のひとこま.

ンについて自由な広がりを見せるのを横目に，プロは ヒトゲノムを全合成すると宣言するし 71 , タンパク質 デザインの時代もすぐそこに迫っているよらだ ${ }^{8)}$.

さあ，あなたなら次に何をつくりますか?

文献

1) Murata, S. et al. (2013) New Gener. Comput. 31, 27-45. DOI: 10.1007/s00354-012-0121-z.

2）石渡信一 (2010) 生物物理 50, 1. DOI: 10.2142/biophys.50.001.

3) http://teamsendai.github.io

4) http://openwetware.org/wiki/Biomod/2013/LMU からの Zhang, T. et al. (2015) J. Am. Chem. Soc. 137, 9776-9779. DOI: 10.1021/ jacs.5b04857.

5）分子ロボティクス研究会編「DNA 分子デザインのすべて 〜 BIOMOD 虎の巻」, CBI 学会 ebook シリーズ第 2 巻 http:// cbi-society.org/home/pub_ebook.html.
6) http://www.molecular-robotics.org/2016/07/4th_wakate/

7) Boeke, J. D. et al. (2016) Science 353, 126-127. DOI: 10.1126/ science.aaf6850.

8) Bale, J. B. et al. (2016) Science 353, 389-394. DOI: $10.1126 /$ science.aaf8818.

\section{佐藤佑介（さとう ゆうすけ）}

東北大学大学院工学研究科ロボティクス専攻, 博士課程後期 2 年・日本学術振興会特別研究員 (DC2)

BIOMOD2011 Team Sendai リーダー. 東北大学工学部機械知能航 空工学科卒. 2015 年より現課程に進学. 16 年より日本学術振興 会特別研究員 (DC2)

研究内容:ベシクル型分子ロボットの構築

連絡先: ๆ 980-8579 宮城県仙台市青葉区荒巻字青葉 6-6-01

E-mail: sato@molbot.mech.tohoku.ac.jp

URL: http://www.molbot.mech.tohoku.ac.jp/

瀧ノ上正浩（たきのうえ まさひろ）

東京工業大学情報理工学院准教授

東京大学理学部物理学科卒. 同. 物理学専攻博士課程修了. 博士 (理学). 京都大学理学研究科博士研究員, 東京大学生産技術研究 所特任助教, 東京工業大学大学院綜合理工学研究科講師および准 教授，JSTさきがけ「細胞構成」兼任を経て，2016 年より現職. 研究内容: 人工細胞・分子ロボット構築に関する生物物理学 連絡先: † 226-8502 神奈川県横浜市緑区長津田町 4259-G3-53 E-mail: takinoue@c.titech.ac.jp, masahiro.takinoue@takinoue-lab.jp URL: http://www.takinoue-lab.jp/

\section{野村 M. 慎一郎（のむら しんいちろう）}

東北大学大学院工学研究科口ボティクス専攻, 准教授 静岡大学工学部卒, 京都大学大学院理学研究科博士 (理学). 21 世紀 COE「歯と骨」特任講師, JST さきがけ「界面」兼任, WPI iCeMS 研究員などを経て 2011 年より現職. 研究内容: 人工細胞工学, 分子ロボティクス 連絡先: $7980-8579$ 宮城県仙台市青葉区荒巻字青葉 6-6-01

E-mail: nomura@molbot.mech.tohoku.ac.jp URL: http://www.molbot.mech.tohoku.ac.jp/ 